\title{
Response to Laparoscopic or open appendicectomy for suspected appendicitis in pregnancy and evaluation of foetal outcome in Australia
}

\author{
Hai T Bui, FRACS and Steven T F Chan. PhD (Lond), FRACS \\ Department of Surgery, Melbourne Medical School - Western Precinct \\ The University of Melbourne, Victoria, Australia \\ Corresponding author: \\ Steven T F Chan \\ Email address: stfc@unimelb.edu.au
}

\section{Dear Editor}

Winter et al. ${ }^{1}$ concluded that open appendicectomy (OA) appears to be a safer approach for pregnant patients with suspected appendicitis. The observational data set was unbalanced with a zero event rate in the OA group and the total event rate was too small for valid regression analysis. Propensity Score Matching (PSM) was used for causal inference. However recent evidence demonstrated that PSM generates higher levels of imbalance, model dependence and bias. ${ }^{2}$ Furthermore, Boosted Regression cannot overcome non-informative predictors or important predictors that have been overlooked ${ }^{3}$

A straightforward test (exact, unconditional) of difference in 2 binomial proportions showed a difference of $5.6 \%$ foetal risk between OA and LA (laparoscopic appendicectomy). As the data were acquired neither by random sampling nor by randomization, there is no population to which one could refer and thus no meaning could be attached to the $95 \%$ confidence interval stated.

The authors claimed that the results showed clinically relevant foetal risk but how was "clinically relevant" defined?

LA for pregnant mothers have consistently demonstrated benefits in terms of shorter operative times, length of stay and fewer postoperative complications compared to OA -- "the best way to take care of the baby is to take care of the mother". ${ }^{4}$

As yet, there is no evidence-based pathophysiological explanation for the observed foetal risk with LA. Until then, there will be conflicting reports in the literature. ${ }^{5}$

To summarise, factors other than the surgical approach might have caused the observed difference and this study has not ruled out bias, confounding and chance and should not serve as an argument against the use of LA for suspected appendicitis in pregnancy. In observational studies causality can be established only on non-statistical grounds.

This is the author manuscript accepted for publication and has undergone full peer review but has not been through the copyediting, typesetting, pagination and proofreading process, which may lead to differences between this version and the Version of Record. Please cite this article as doi: 10.1111/ans.13864

This article is protected by copyright. All rights reserved. 
"Word Count: 280 main text; References 4 (excluding original source).

\section{References}

\section{var}

1. Laparoscopic or open appendicectomy for suspected appendicitis in pregnancy and evaluation of foetal outcome in Australia. ANZ. J doi: 10.1111/ans.13750.

2. King G, Nielsen R. Why propensity scores should not be used for matching. http://j.mp/1sexgVw

(accessed 28 ${ }^{\text {th }}$ Oct 2016).

3. Kuhn M, Johnson K. Applied predictive modelling. Springer New York, 2013.

4. Cox TC, Huntington CR, Blair $\mathrm{L}$, et al. Laparoscopic appendectomy and cholecystectomy versus open: a study of 1999 pregnant patients. Surg Endos 2016; 30: 593-602.

5. Lausten JF, Bjerring OS, Johannesssen O, Qvist N. Laparoscopic appendectomy during pregnancy is safe for both the mother and the fetus. Danish Medical journal 2016; 63: A5259.

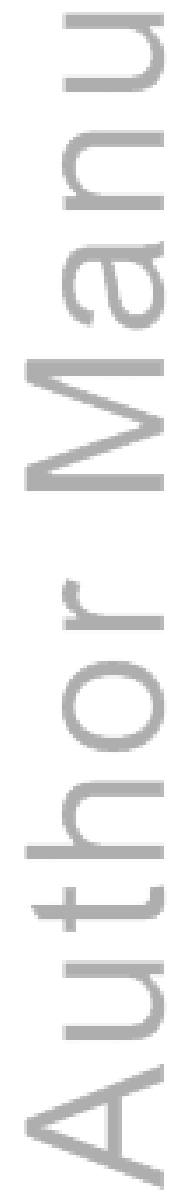

This article is protected by copyright. All rights reserved. 


\section{University Library}

\section{- M M N E R VA A gateway to Melbourne's research publications}

Minerva Access is the Institutional Repository of The University of Melbourne

Author/s:

Bui, HT;Chan, STF

Title:

Re: Laparoscopic or open appendicectomy for suspected appendicitis in pregnancy and evaluation of foetal outcome in Australia

Date:

2017-05-01

Citation:

Bui, H. T. \& Chan, S. T. F. (2017). Re: Laparoscopic or open appendicectomy for suspected appendicitis in pregnancy and evaluation of foetal outcome in Australia. ANZ JOURNAL OF SURGERY, 87 (5), pp.420-420. https://doi.org/10.1111/ans.13864.

Persistent Link:

http://hdl.handle.net/11343/292829 